\title{
Assessment of Heavy Metals and Bioaccumulation in Periwinkle (Tympanotonus fuscatus var. radula (L.))Obtained from the Upper Reaches of the Bonny Estuary, Nigeria
}

\section{Miebaka Moslen*, Ikem KE Ekweozor and Nsirim-Dimkpa Nwoka}

Department of Animal and Environmental Biology, Rivers State University, Port Harcourt, Nigeria

*Corresponding author: Moslen M, Department of Animal and Environmental Biology, Rivers State University, Port Harcourt, Nigeria, Tel: +234(0)8056022347; E-mail: moslen4c@yahoo.com

Received date: November 03, 2017; Accepted date: November 20, 2017; Published date: November 29,2017

Copyright: (C) 2017 Moslen M, et al. This is an open-access article distributed under the terms of the Creative Commons Attribution License, which permits unrestricted use, distribution, and reproduction in any medium, provided the original author and source are credited.

Citation: Moslen M, Ekweozor IKE, Nwoka ND (2017) Assessment of Heavy Metals and Bioaccumulation in Periwinkle (Tympanotonus fuscatus var. radula (L.) ) Obtained from the upper Reaches of the Bonny Estuary, Nigeria. J Heavy Met Toxicity Dis. Vol. 2 No. 2: 3.

\section{Abstract}

The aim of this study was to assess accumulation of heavy metals in tissues of Periwinkle (Tympanotonus fuscatus var radula (L.) obtained from Azuabie creek using Okujagu creek as control location. Fifty samples were collected from each site for three months (October-December 2015). Atomic Absorption Spectrophotometric technique was used in heavy metal analysis. Mean metal concentrations in sediments were as follows $\mathrm{Zn}: 178.08$ $\mathrm{mgkg}^{-1}$; $\mathrm{Cd}$ : $0.3 \mathrm{mgkg}^{-1}$; $\mathrm{Cr}: 14.27 \mathrm{mgkg}^{-1}$ and $\mathrm{Pb}: 18.75$ $\mathrm{mgkg}^{-1}$. While those in Periwinkle tissue with biosediment accumulation factor (BAF) in parenthesis were thus $\mathrm{Zn}$ : $24.42 \mathrm{mgkg}^{-1}$ (0.137); Cd: $0.02 \mathrm{mgkg}^{-1}$ (0.067); Cr: 1.57 $\mathrm{mgkg}^{-1}(0.11)$ and $\left.\mathrm{Pb} 0.01 \mathrm{mgkg}^{-1} 0.001\right)$. The result of BAF of metals indicated low values which could be related to assimilation and excretion rate of heavy metals in the organisms examined. Variations in the concentration of $\mathrm{Zn}$ in the gastropod tissues showed significant difference $(p<0.01)$ between sites, likewise, $\mathrm{Cr}(p<0.001)$ and $\mathrm{Cd}$ $(p<0.05)$. In conclusion, comparison between the two creeks showed that tissue samples from St1, St2 and St3 (Azuabie creek) had higher concentration of metals in relation to the control station (Okujagu creek) indicating potentials for accumulation, mainly due to differences in anthropogenic activities. $\mathrm{Cr}, \mathrm{Cd}$ and $\mathrm{Pb}$ concentrations in tissue had mean values less than the recommended limits in seafood by FAO/WHO however, regular monitoring is required to observe perturbations.

Keywords: Heavy metals; Bioaccumulation; Periwinkles; Bonny Estuary

\section{Introduction}

Human activities have caused levels of heavy metals in the environment to increase. Metal concentrations in biota are generally low, except in the vicinity of metal pollution [1].
Many aquatic organisms for example Periwinkles have the ability to accumulate and biomagnify contaminants like heavy metals, polycyclic aromatic hydrocarbons and $\mathrm{PCB}$ in the environment [2]. An ideal bio-indicator (biomonitor) should satisfy certain criteria as reviewed [3-5]. These include the ability to accumulate pollutants without being killed by the levels encountered in the environment; sedentary in order to be representative of the study area, sufficiently long lived to allow the sampling of more than one year-class, if desired: be of reasonable size, giving adequate tissue for analysis. According to Daka et al. [6] the gastropod mollusc Tympanotonus fuscatus var. radulas (L.) appear to satisfy a number of the criteria listed above. Its suitability is universally recognized, being included in most of the national environmental monitoring programmes of marine and brackish water pollution [7]. In this study, pollutants such as $\mathrm{Cr}, \mathrm{Cd}, \mathrm{Pb}$ and $\mathrm{Zn}$ were considered which are capable of bioaccumulation in the tissues of aquatic organisms. Monitoring of levels of contaminants in environmental receptors can include the measurement of bioaccumulation and toxicants in the bodies of organisms [8]. Some invertebrates especially molluscs and crustaceans can accumulate heavy metals many hundred folds and therefore can raise the level which may be of no significance in water to the point at which their tissue become highly hazardous to organisms that consume them. Heavy metals are accumulated by marine organisms to very high concentrations in their tissue and hence their body concentrations are easily measured. This may be influenced by rate of contamination and usually provides a time integrated measure of heavy metal supply over weeks, months or even years according to the specifics analysed [9]. Ekweozor [10] then stated that the body content of a trace metal in any organism results from the net balance between the processes of metal uptake and metal loss. The Periwinkle (Tympanotonus fuscatus var radula (L.) is a mollusc (Gastropods) of high commercial and economic value in the Niger Delta region of Nigeria. It is commonly distributed and found in the mangrove swamps and intertidal zones of estuarine and marine waters of the Niger Delta. They are deposit feeders and bioindicators of heavy metal and hydrocarbon pollution in the aquatic 
environment. Deposit feeding has to do with sediment and benthic dwellers. This implies the organisms have the ability to bioaccumulate heavy metals in their tissues in the process of deposit-feeding and so integrate the environmental conditions of the water and sediment over time. Studies have also been conducted to show the concentration of heavy metals in this mollusc and other commercial fish species of economic value to determine hazardous level of contaminants in them with regards to human consumption [11,12,2,13-15]. Azubie creek receives waste input more compared to adjacent Okujagu creek. The aim of this study was to assess heavy metal accumulation and determine biosediment accumulation factor (BAF) in Periwinkles (Tympanotonus fuscatus var radula (L.) obtained from Azuabie creek using Okujagu creek as a control site.

\section{Materials and Methods}

\section{Study site and sample collection}

The study site was Azuabie creek, a tributary of the upper Bonny estuary in the Niger Delta, Nigeria (Figure 1). It is tidal with exposed mudflats at low tide. Proximity of this creek to nearby settlements, city abattoir and the Trans-Amadi industrial layout predisposes the creek to industrial, municipal and domestic wastes discharge. Three stations (ST1, ST2, and ST3) were established on Azuabie creek while a control station (Control) was established on a less impacted creek (Okujagu) parallel to the Azuabie creek. Sediment samples were collected with an Ekman grab of $15 \mathrm{~cm} \times 15 \mathrm{~cm}$ from the top layers. Duplicate sediment samples were collected at the established stations and wrapped in aluminum foil with labels. Fifty samples of Periwinkle (Tympanotonus fuscatus) were randomly collected from each station, washed and put in well labeled plastic containers. Periwinkle samples were collected by handpicking during mid-tide level (MTL) and mean low tide levels (MLTL) at the intertidal flats of mangrove swamps. All samples were preserved in ice-packed coolers while in transit before laboratory analysis.

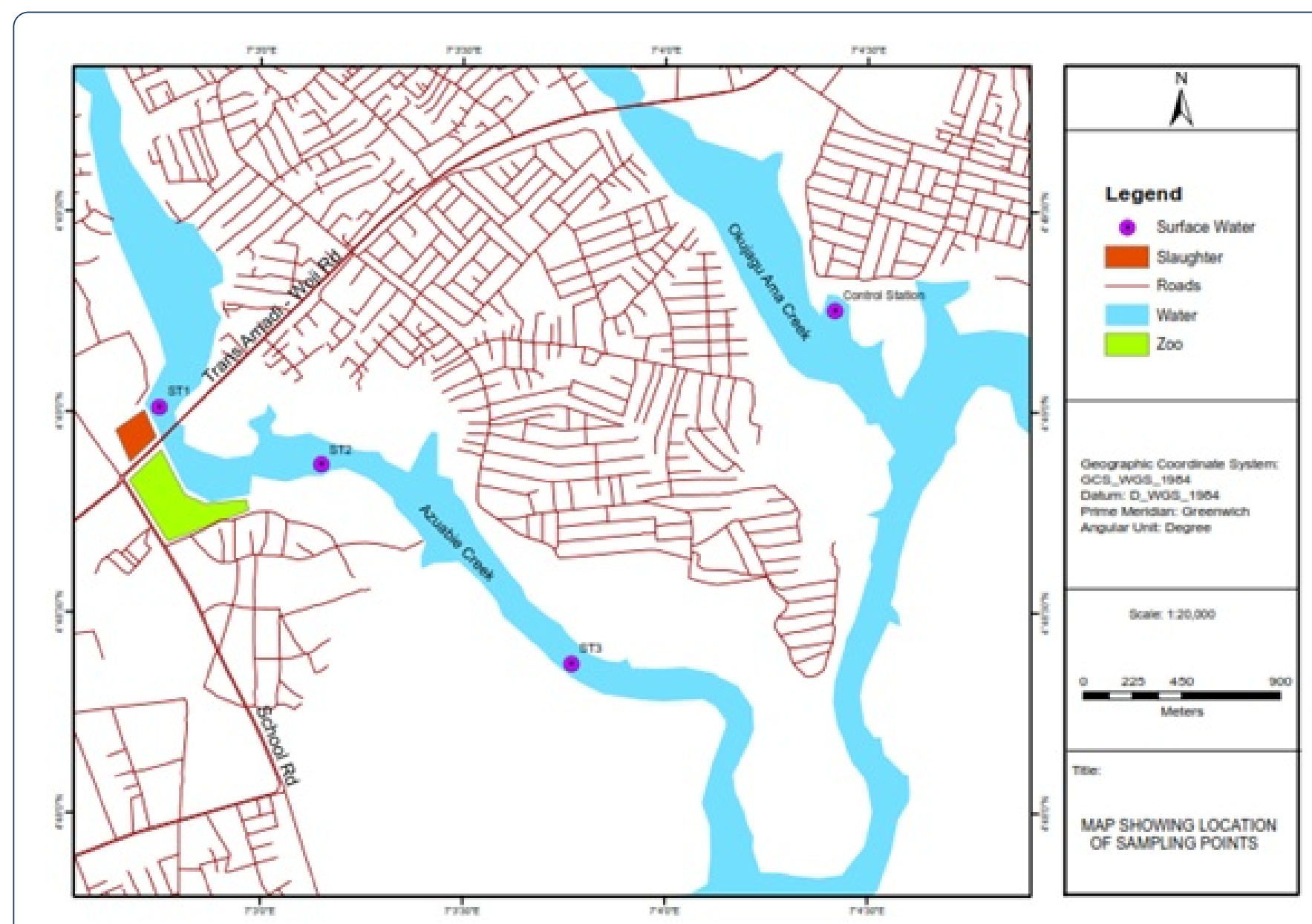

Figure 1 Map of Study site with sampled points.

\section{Analysis of sediment for heavy metals}

Small quantities of the sediment samples were air-dried under room temperature and ground to powder using local blender and sieved through $63 \mu \mathrm{m}$ mesh. Then $2 \mathrm{~g}$ of each was digested with Aqua-regia (mixture of $\mathrm{HCl}$ and $\mathrm{HNO} 3$ in the ratio of $3: 1$ ). The digested sediment samples were filtered with 
$20 \mathrm{ml}$ of de-ionized water and the filtrates were stored in clean acid-washed and appropriately labeled $30 \mathrm{ml}$ sample containers. Analysis was done using Atomic Absorption Spectrophotometer, AAS (Model 210VGP BUCK Scientific, USA). The limit of detection (LOD) of the equipment used was $0.001 \mathrm{mg} / \mathrm{kg}$. Quality assurance quality control measures included blank determination, triplicate sample run and intermittent analysis of quality check standard for each metal examined.

\section{Analysis of heavy metals in Periwinkle Tissue}

Periwinkles tissue was removed from the shell with a clean acid washed stainless steel needle and dried to constant weight at $90^{\circ} \mathrm{C}$ for two days in clean acid washed petri dishes. After drying, the samples were kept in a desiccator and allowed to cool. The samples were then crushed into fine powders using porcelain mortar and pestle. Samples were digested by microwave digestion method. In this method of digestion, nitric acid (analar grade) and hydrogen peroxide (analar grade) in the ratio of 3:1 were added to the samples. The mixtures were then digested at $150^{\circ} \mathrm{C}$ for $30 \mathrm{~min}$ in microwave oven. The Hydrogen peroxide and nitric acid added reduces nitrous vapour and speeds up digestion of organic substances by increasing the temperature of reaction in the digestion process. The digested samples were filtered with 20 $\mathrm{ml}$ of deionized water. The filtrates were collected with clean acid-washed and appropriately labeled $30 \mathrm{ml}$ polyethylene containers for analysis by Atomic Absorption Spectrophotometric method (AAS-Model 210VGP BUCK Scientific, USA).

Statistics: Analysis of variance was done using the General linear model in order to detect significant differences in the concentration of heavy metals both in sediments and tissues of Periwinkles between the stations examined. The software package Minitab 16 was used for the analysis.

\section{Results and Discussion}

The summary result of heavy metal analysis in sediment Periwinkle and biosediment accumulation factor (BAF) is presented in Table 1.

Table 1 Mean heavy metal concentrations in sediment, Periwinkle and BAF values.

\begin{tabular}{|l|l|l|l|l|l|}
\hline $\begin{array}{l}\text { Heavy } \\
\text { Metal }\end{array}$ & Minimum & Maximum & $\begin{array}{l}\text { Mean } \\
\text { (onc. of } \\
\text { sediment } \\
\text { (mgkg- }^{-1} \text { ) }\end{array}$ & $\begin{array}{l}\text { Mean } \\
\text { conc. of } \\
\text { biota } \\
\text { (mgkg-1 }^{-1}\end{array}$ & BAF \\
\hline $\mathrm{Cr}$ & 0.01 & 58.8 & 14.27 & 1.57 & 0.11 \\
\hline $\mathrm{Zn}$ & 31.6 & 302.1 & 178.08 & 24.42 & 0.137 \\
\hline $\mathrm{Cd}$ & 0.01 & 0.6 & 0.3 & 0.02 & 0.067 \\
\hline $\mathrm{Pb}$ & 4.49 & 40.2 & 18.75 & 0.01 & 0.001 \\
\hline
\end{tabular}

The concentration of $\mathrm{Cr}$ in sediment ranged from 0.01 to $58.8 \mathrm{mgkg}^{-1}$ with a mean value of $14.7 \mathrm{mgkg}^{-1}$ while $\mathrm{Zn}$ had higher concentrations ( 31.6 to $302.1 \mathrm{mgkg}^{-1}$ ) compared to other metals. The lowest value of $\mathrm{Pb}$ in sediment was 4.49 $\mathrm{mgkg}^{-1}$ and the highest value was $40.2 \mathrm{mgkg}^{-1}$ with mean of $18.75 \mathrm{mgkg}^{-1}$ while levels of $\mathrm{Cr}$ in sediments had a mean value of $14.27 \mathrm{mgkg}^{-1}$. The concentration of $\mathrm{Zn}$ in sediments was the only one with significant difference $(p<0.05)$ between the stations examined.

Tukey test showed that the significant difference actually occurred thus: St $1<\mathrm{St} 2=\mathrm{St} 3<$ control station. The level of heavy metals in the Periwinkle (Tympanotonus fuscatus) tissue differed across sites with Zn having higher values, followed by $\mathrm{Cr}$ compared to other metals (Figure 2).

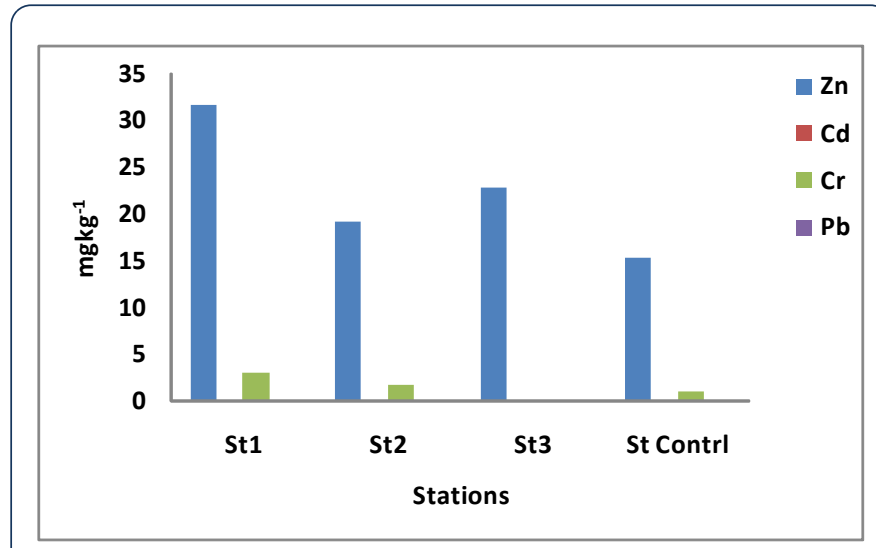

Figure 2 Concentration of heavy metals in tissues of Tympanotonus tissue across stations.

The concentration of metals found in the gastropod tissue at the control station was less compared to the other three stations on Azuabie creek. The variations in the concentration of $\mathrm{Zn}$ in the gastropod tissues was significantly different $(p<0.01)$ between stations (Table 2). Similarly the level of $\mathrm{Cr}$ in tissue showed significant difference $(p<0.001)$ likewise, $C d$ $(p<0.05)$ between the stations examined. Post hoc analysis using Tukey test gave actual significant difference for each metal thus: Zn, St. $1<$ St.3=St2=St.4; Cr, St.1<St.2<St.St.3; Cd, St. $3<$ St1=St.4<St.2. Comparison between the two creeks showed that tissue samples from St1, St2 and St3 (Azuabie creek) had higher concentration of metals than those from the control station (Okujagu creek) due to the influence of higher human activities around Azuabie creek compared to the control station at Okujagu creek. The result of this study compared favourably with the concentration sequence of metal ( $\mathrm{Fe}>\mathrm{Zn}>\mathrm{Cr}>\mathrm{Pb}$ ) obtained by [16] in T. fuscatus but actual metal concentration differed considerably. ljeomah et al. (2015) reported the following mean values in $T$. fuscatus in an oil polluted site; Cd $0.028 \mathrm{mgkg}^{-1}$; $\mathrm{Cr} 0.04 \mathrm{mgkg}^{-1}$; Ni 0.805 $\mathrm{mgkg}^{-1}$; P $0.63 \mathrm{mgkg}^{-1}$; Zn $21.03 \mathrm{mgkg}^{-1}$ which also compared with values obtained in this study. The bio-sediment accumulation factor (BAF) in the current study indicated that $\mathrm{Zn}>\mathrm{Cr}>\mathrm{Cd}>\mathrm{Pb}$ with the highest ratio of 0.137 and lowest of 0.001. Canterford et al. [17] stated that it is useful to express results in terms of biological concentration factor (BCF) when comparing the order of uptake of metals. The BAF result obtained in the current study indicated low values compared to other studies which could be related to assimilation and 
excretion rate of heavy metals in organisms with respect to the surrounding environment. Davies et al. [2] reported BCF range of 1.00-4.83 for small and large size Periwinkles which were higher compared to values obtained in this study. The BAF observed in the current study were also generally less than those reported by Chindah et al. [18] during the wet season $[\mathrm{Zn} \quad(2.23)>\mathrm{Pb}(2.14)>\mathrm{Cd}(0.33)>\mathrm{V}(0.29)>\mathrm{Cr}(0.03)]$ but higher than the values obtained during the dry season [ $\mathrm{Zn}$ $(0.016)>\mathrm{Pb}(0)=\mathrm{Cd}(0)=\mathrm{V}(0)=\mathrm{Cr}(0)]$ for $T$. fuscatus in the Niger Delta. Javed and Usmani (2013) reported high BAF value for liver (233.27-5806.5) and least for integument (35.97-560.36) in tissues of Mastacembelus armatus. A bioconcentration factor greater than 1 is indicative of hydrophobic or lipophilic chemical. It is an indicator of how probable a chemical is to bioaccumulate [19].

Table 2 ANOVA with F-values for sediment and tissues concentrations of metals.

\begin{tabular}{|l|l|}
\hline Heavy metals & Location (F-values) \\
\hline Sediment & $7.03^{*}$ \\
\hline $\mathrm{Zn}$ & $1.00 \mathrm{~ns}$ \\
\hline $\mathrm{Cd}$ & $4.32 \mathrm{~ns}$ \\
\hline $\mathrm{Cr}$ & $4.32 \mathrm{~ns}$ \\
\hline $\mathrm{Pb}$ & \\
\hline $\mathrm{Tissue}$ & $13.71^{* *}$ \\
\hline $\mathrm{Zn}$ & $6.0 \mathrm{~ns}$ \\
\hline $\mathrm{Cd}$ & $31.84^{* * *}$ \\
\hline $\mathrm{Cr}$ & $\mathrm{nr}$ \\
\hline $\mathrm{Pb}$ & ${ }^{*}=\mathrm{P}<0.05{ }^{* * *} \mathrm{P}<0.01 ;{ }^{* * *}=\mathrm{P}<0.001 ;$ ns $=($ not significant $), \mathrm{nr}=($ no result $)$ \\
\hline
\end{tabular}

According to Daka et al. [6] T. fuscatus is a good candidate for the biomonitoring of $\mathrm{Cd}$ but not for $\mathrm{Zn}$ and $\mathrm{Cu}$ stating that the ambient concentration of $\mathrm{Cu}$ and $\mathrm{Zn}$ may affect the accumulation of $\mathrm{Cd}$ and need to be considered in the interpretation of Cd data in T. fuscatus. Daka et al. [20] also reported that size of $T$. fuscatus and salinity of the water affect bioaccumulation of heavy metals in $T$. fuscatus. The concentration of $\mathrm{Cd}$ in $T$. fuscatus observed in this study however, contrast with the report of [21] in a study of heavy metals in sea food crab (Callinectes amnicola) and Periwinkle (Tympanotonus fuscatus) collected from Uta Ewa Creek. According to Davies et al. [2], a comprehensive report shows the accumulation of three metals; Chromium, Cadmium and Lead in $T$. fuscatus (shell and soft tissue), water and sediment collected from four stations along Eleechi creek, Niger Delta. Molluscs are also sturdy enough to survive in laboratory and field studies and tolerant to environmental alterations, and various contaminants. Contaminations of $\mathrm{Pb}$ in sediment have detrimental effect on benthic organism [9]. The highest concentration of Lead $(\mathrm{Pb})$ in Tympanotonus fuscatus $(0.02$ $\mathrm{mgkg}^{-1}$ ) was observed at St1 and was not detected in other stations indicating low contamination in biota. This compares with the values of metals recorded in $M$. macrobrachion for $\mathrm{Pb}, 0.032 \pm 0.002 \mathrm{mgkg}^{-1}$ while the value of $\mathrm{Pb}$ in $T$. fuscatus was $0.119 \pm 0.176 \mathrm{mgkg}^{-1}$. This could be as a result of the level of metals in the sediment that was taken up and concentrated by the biota. [14] in a study of heavy metal concentration in tissues of Sarotherodon melanotheron obtained from Azuabie creek reported that metal concentration in fish tissue were in the order $\mathrm{Cu}>\mathrm{Pb}>\mathrm{Cr}>\mathrm{Ni}>\mathrm{Ag}>\mathrm{Cd}$ with the following mean values $5.59 \pm 1.06 \mathrm{mgkg}^{-1}, 5.12 \pm 1.23 \mathrm{mgkg}^{-1}, 2.69 \pm 1.44$ $\mathrm{mgkg}^{-1}, 1.94 \pm 0.34 \mathrm{mgkg}^{-1}, 1.02 \pm 0.34 \mathrm{mgkg}^{-1}$ and $0.38 \pm 0.08$ $\mathrm{mgkg}^{-1}$ respectively. According to [15] in another study of the Azuabie creek reported mean metal concentrations in tissues of Mugil cephalus as follows $\mathrm{Cr} 1.96 \pm 0.81 \mathrm{mgkg}^{-1}$, Ni $1.82 \pm$ $0.40 \mathrm{mgkg}^{-1}, \mathrm{Cu} 4.12 \pm 1.07 \mathrm{mgkg}^{-1}, \mathrm{~Pb} 2.96 \pm 0.67 \mathrm{mgkg}^{-1}, \mathrm{Ag}$ $1.20 \pm 0.33 \mathrm{mgkg}^{-1}$ and $\mathrm{Cd} 0.33 \pm 0.09 \mathrm{mgkg}^{-1}$. These researches corroborate the findings of the current study on the presence of heavy metals in the study area. However, the mean values of $\mathrm{Cr}, \mathrm{Pb}$ and $\mathrm{Cd}$ found in the tissue of Tympanotonus fuscatus of the current study were below the recommended limits in seafood [22-24] respectively. In another study of heavy metal concentrations in tissues of mudskipper (Periophthalmus sp) a benthic feeder obtained from the Azuabie creek [13] found mean values of $\mathrm{Cr}, \mathrm{Ni}, \mathrm{Pb}$ and Ag above the limits in sea food set by [25] and FAO [26] and concluded that metal concentrations in fish tissues above regulatory limits suggests the ability of mudskippers to bioaccumulate and bio-magnify the metal pollutants without physical signs of distress and this is applicable to $T$. fuscatus in the current study. In conclusion gastropods ( $T$. fuscatus) obtained from Azuabie creek concentrated heavy metals in their tissue. Generally tissue concentration of metals was in the order of $\mathrm{Zn}>\mathrm{Cr}>\mathrm{Cd}>\mathrm{Pb}$ with mean values of the latter three less than the recommended limits in seafood. Higher values of metal concentration were obtained in Periwinkle tissues collected from Azuabie creek compared to the control station at Okujagu indicating potential build up and more contamination than the control creek. This is an implication for regular monitoring to identify perturbations.

\section{Conflict of Interest}

Authors categorically state that there is no conflict of interest and that research was solely funded by authors.

\section{References}

1. Lindqvist L, Block M (1995) Excretion of cadmium during moulting and metamorphosis in Tenebrio molitor (Coleoptera; Tenebrionidae). Comp Biochem Phys 111: 325-328.

2. Davies OA, Allison ME, Uyi HS (2006) Bioaccumulation of heavy metals in water, sediment and Periwinkle (Tympanotonus fuscatus var radula) from the Elechi Creek, Niger Delta. African J of Biotechnol 5: 968-973.

3. Phillips DJH (1980) Quantitative aquatic biological indicators. Pollution monitoring series. Applied Sc. Barking Publishers, London.

4. Philips DJH, Rainbow PS (1993) Biomonitoring of trace aquatic contaminants. Environmental Management Series. Elsevier Applied Science, London. 571. 
5. Langston WJ, Spence SK (1994) Metal Analysis. In: Calow P (ed) Handbook of Ecotoxicology, Blackwell Scientific, Oxford, Uk. pp: 45-78.

6. Daka ER, Ifidi I, Braide SA (2006) Accumulation of heavy metals from single and mixed metal solutions by the gastropod mollusk Tympanotonus fuscatus Linnaeus from a Niger Delta estuary: Implications for biomonitoring. African J of Biotechnol 5: 1954-1962.

7. Widdows J, Donkin P, Brinsley MD, Evans SV, Salkeld PN, et al. (1995) Scope for growth and contaminant levels in North Sea mussels Mytilus edulis. Mar Ecol Prog Ser 127: 131-148.

8. Depledge MH, Hopkin SP (1995) Methods to assess effects on brackish, estuarine and near-coastal water organism In: SCOPE 53. Methods to assess the effect of chemicals on Ecosystems. Lithurst RA, Bourdeau P, Tardiff RJ (eds). pp: 125-149.

9. Dambo WB, Ekweozor IKE (2000) The determination of lead in mangrove oyster, Crassostrea gasar from the lower bonny estuary, Nigeria. J of Appl Sci and Environ Managt 4: 101-108.

10. Ekweozor IKE (2014) Appraisal of industrialization and environmental pollution: A marine biology perspective. 29th Inaugural lecture of the Rivers State University of Science \& Technology, Port Harcourt, Nigeria. 185.

11. Biney CA (1991) The distribution of terrace heavy metals in the Kpong Headpond and lower Volta River Ghana. In: Perspectives in aquatic entomology. Shastree NKK (ed) Marendre Publishing House, Delhi, India.

12. Okoye BCO (1991) Heavy metal and organisms in the Lagos lagoon. International Studies 37: 285-295.

13. Moslen M, Miebaka CA (2016) Temporal variation of heavy metal concentrations in Periopthalmus sp. obtained from Azuabie Creek in the Upper Bonny Estuary, Nigeria. Current Studies in Comparative Education. Sci and Technol 3:136-147.

14. Moslen M, Miebaka CA (2017) Concentration of heavy metals and health risk assessment of consumption of fish (Sarotherodon melanotheron) from an Estuarine Creek in the Niger Delta, Nigeria. IOSR J of Environ Sci, Toxicol and Food Technol 11: 68-73.

15. Moslen M (2017) Risk assessment and bioconcentration of heavy metals in Mugil Cephalus (Mullet) obtained from Azuabie Creek in Port Harcourt, Nigeria. J of Res in Environ and Earth Sci 3: 01-07.
16. Ikejimba CC, Sakpa SS (2014) Comparative study of some heavy metals' concentrations in water and Tympanotonus fuscatus var radula samples of Egbokodo River, Warri, Nigeria. Inter J of Modern Bio Res 2: 7-15.

17. Canterford GS, Bichanan AS, Ducker SC (1978) Accumulation of heavy metals by the marine diatom Ditylum brightrelli (west) Grunow. Aust J Mar Freshwater Res 29: 611-622.

18. Chindah ACl, Braide SA, Amakiri J, Chikwendu SON (2009) Heavy metal concentrations in sediment and Periwinkle-tympanotonus fuscastus in the different ecological zones of Bonny River System, Niger Delta, Nigeria. The Open Environ Pollut \& Toxicol J 1: 93-106.

19. Landis WG, Sofield RM, Yu MH (2011) Introduction to environmental toxicology: Molecular structures to ecological landscapes. 4th edn. Boca Raton, FL: CRC Press. 117-162.

20. Daka ER, Ifidi I, Braide SA (2006) Effect of size and salinity on the accumulation of heavy metals in the intertidal gastropod Tympanotonus fuscatus Linnaeus. African J of Environ Pollut and Health 2006 5: 1-7.

21. Emmanuel JU (2014) Assessment of heavy metals concentration in water, sediments and some common sea foods Callinectes amnicola and Tympanotonus fuscatus (crabs and Periwinkles) from Uta ewa creek of Ikot Abasi, Akwa Ibom state, Nigeria. Inter J of Appl Environ Sci 4: 99-106.

22. USFDA (1993) Food and drug administration, guidance document for nickel in shell fish. DHHS/PHS/FDA/CFSAN/office of seafood, Washington, DC.

23. FAO/WHO (1989) Evaluation of certain food additives and the contaminants mercury, lead and cadmium; WHO Technical Report Series No. 505, 1989.

24. FAO (2003) Heavy Metals Regulations: Part 1. Legal Notice no. 66.

25. WHO (1985) (Guidelines for Drinking Water Quality (ii): Health Criteria and Supporting Information. Vol. 1, Recommendations. WHO, Geneva. p: 130.

26. FAO (1983) Compilation of legal limits for hazardous substances in fish and fishery products. FAO Fishery Circular, No. 464: 5-100. 